\title{
Omkring et par tidlige kort over Tranquebar
}

af afdelingsbibliotekar Bjørn Westerbeek Dahl, Københavns Rådhusbibliotek

I 1671 blev den danske besiddelse Tranquebar på Indiens østkyst, Coromandelkysten, genstand for en omhyggelig opmåling af sachseren Jacob Storzell (Stärzell). Hans kort, der nu er tabt, blev efter at være sendt til København kopieret i to exemplarer, der begge findes i Det kongelige Biblioteks Kortsamling. Det ene af disse er tegnet af ingeniøren Franciscus de Hammersheimb, der var i den danske konges tjeneste fra 1674 til sin død i 1692, og blev erhvervet af biblioteket, da man i 1911 fik overladt det daværende Ingeniørkorps' store bestand af kort over fremmede lokaliteter ${ }^{1}$. Det andet kort (ill. 1) hører til den del af de gamle kongelige kort- og billedsamlinger, der i midten af 1700-tallet blev samlet i det store protokolværk, der nu går under navnet Frederik den 5's Atlas. Dette kort er usigneret, men den karakteristiske håndskrift, der ses i den lange text på indexet, stemmer nøje med militæringeniøren Gottfried Hoffmanns skrift, at det må betragtes som højst sandsynligt, at kortet er et af hans mange kortarbejder ${ }^{2}$. I 1671 blev han udnævnt til militærkartograf og begyndte en omfattende indsamling og rentegning af ældre kortarbejder. Storzells kort, eller en kopi af det, har været et af dem.

De to kort er velbevarede, og deres let aflæselige indhold giver eftertiden et glimrende indtryk af den danske frstning som den var i 1671. Tidspunktet er bemærkelsesværdigt: To år tidligere var „Færø“ ankret op som det første danske skib på Tranquebars red siden 1639, og samtidigt etableredes i København et nyt Ostindisk Kompagni, der i de følgende år jævnligt udsendte skibe til kolonien. Jacob Storzell, der ikke er kendt fra andre kilder, må have været med på en af dem, og hans opmåling har velsagtens været udført på opdrag af det ny kompagni. Hans kort - eller rettere de to kopier af det, der er bevaret til vore dage - er bemærkelses- 


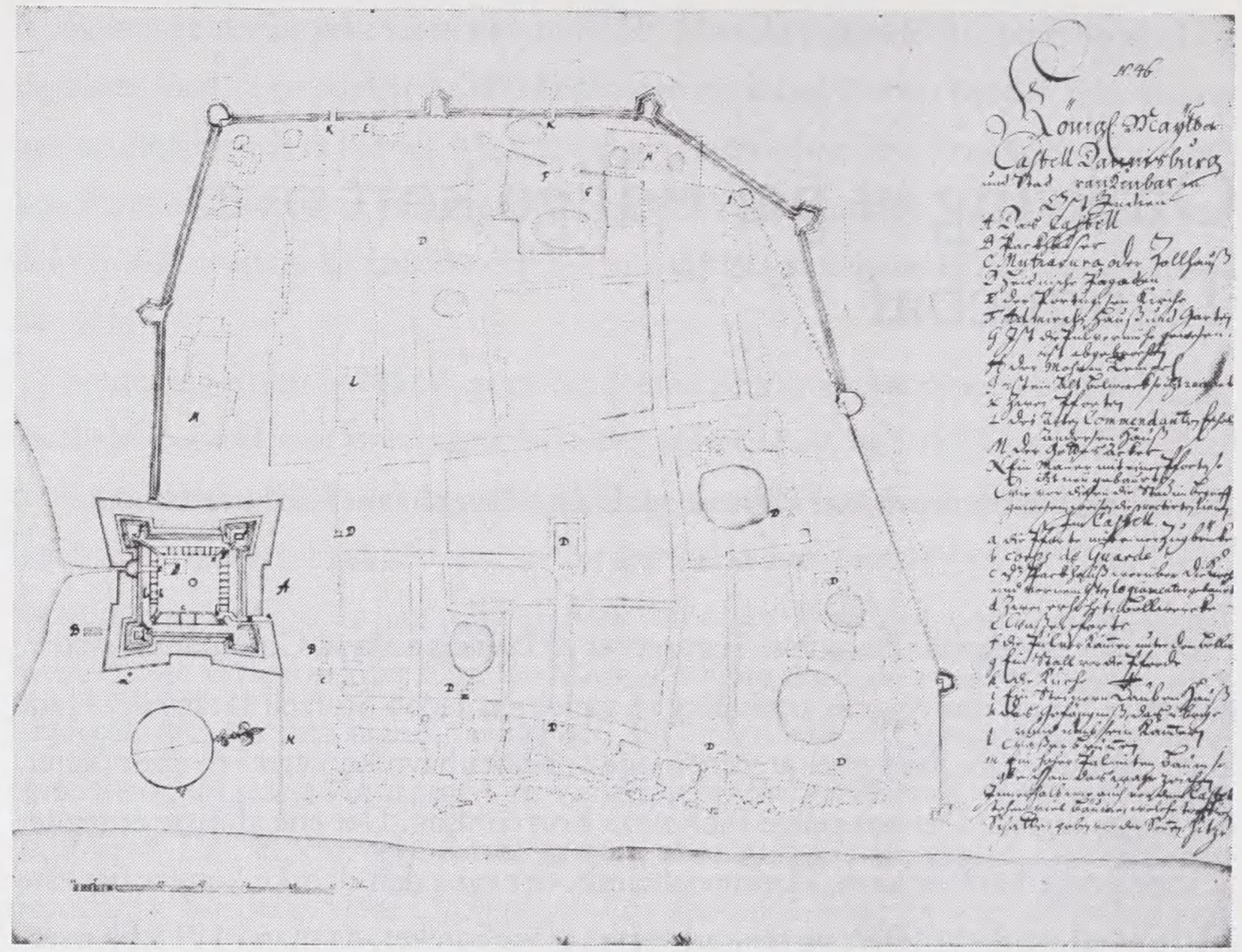

Ill. 1. Gottfried Hoffmanns kopi af Jacob Storzells kort over Tranquebar fra 1671. Frederik den 5.s Atlas, bd. 48, nr. 46.

værdigt ved for førte gang at præsentere en befæstning omkring hele Tranquebar by. Tilmed afdækker det en overset fase i byens ældre historie, der synes at antyde, at Tranquebar også havde været befæstet, før danskernes ankomst til stedet i 1620.

$\mathrm{Da}$ Giedde i oktober 1620 var ankommet til Tranquebar, påbegyndte han opførelsen af kastellet Dansborg, hvad han fortæller om i de upublicerede dele af sin journal: Den 7. december 1620 forlod han sit skib for at „lade frstningen forfærdige" og knap to uger senere akkorderede han med sin sergent og sin fændrik om at bruge dem som konduktører ved byggeriet. Hensigten var at få „voldene ret lagt og tørvene stukket på korrekt vis. "Herefter er de to konduktører vel gået igang med at lægge jordvoldene og finde egnede græstørv. Imens indgik Giedde en kontrakt med nogle murermestre, der skulle bygge en hvælvet port og en vagtbygning. De skulle begge stå færdige på 40 dage at regne fra den 24. december 1620 .

Da Giedde den 13. februar 1621 forlod Tranquebar, var arbejdet med Dansborg så fremskredet, at der var lagt kanoner på voldene, men hvorledes fæstningen så ud i detaljer, ved vi ikke³. 
Ganske vist besøgte islændingen Jon Olofsson Tranquebar i 1623 og beskrev fæstningen som „muret og herligt udrustet med ronddele på hvert hjørne“, hvad der gemmer sig bag denne overfladiske beskrivelse er tvivlsomt, men selvom ordet rondel på dette tidspunkt bruges i flæng med betegnelsen for bastion, synes grundkonceptet af Dansborg fra 1620-21 at være identisk med, hvad vi genkender fra 1671-planerne ${ }^{4}$.

Hvad man imidlertid kan komme i tvivl om, er hvad Jon Olafsson mener med at „fæstningen var muret“: Hvis han mente, at porten og de militære bygninger inden for volden var bygget af tegl, er det utvivlsomt korrekt, og alene det har sikkert gjort indtryk på Olafsson, der ikke var vant til den slags fra sit soldaterliv i Danmark - endsige fra sin barndom på Island. Til gengæld kan det næppe være fæstningsværkerne, der hentydes til, for i 1640'erne blev de med anvendelse af store midler og megen arbejdskaft beklædt med mursten og i de bevarede, meget detaljerede regnskaber synes der ikke at være antydning af, at de afløser en ældre murbeklædning. Bemærkelsesværdigt er det i denne sammenhæng, at Giedde ikke nævner andre kontakter til håndværkere end de allerede omtalte murermestre, og en beklædning af selv en lav mur omkring hans Dansborg må have involveret mængder af teglbrændere, murere og kalkslagere. Blot omkredsen af muren er ca. $550 \mathrm{~m}$, hvortil kommer, at højden må have været mindst $21 / 2$ til $3 \mathrm{~m}$ for at kunne opfylde sit formål.

Der blev ikke brugt alverden på vedligeholdelsen af Dansborg i 1620'erne og det følgende tiår. Først da den energiske Willem Leyel i 1644 havde indtaget sin post som kommandant, blev Gieddes nu helt forfaldne jordanlæg genstand for en systematisk restaurering og modernisering 5 .

Bygningerne inde i Dansborg var i en elendig tilstand, skrev Leyel hjem til København. Også fæstningsværkerne var i en miserabel forfatning: Broen foran Gieddes anlæg var opført af tømmer, som i Tranquebars klima mildest talt var uegnet, fornyedes allerede i efteråret 1644 i murværk, ligesom den murede port blev repareret.

Til brug for de følgende års arbejder havde han bestilt sten, kalk og andre materialer, og han planlagde at udstyre bastionerne med en „foed af Steen Runden af Festningen Under Woldene udi Graffuerne“, hvad de tilsyneladende ikke havde haft tidligere. Hermed synes formodningen om, at Gieddes anlæg var opført som et jordværk, at være bekræftet.

I slutningen af 1645 skriver Leyel, at han havde revet to af bastionerne ned og 


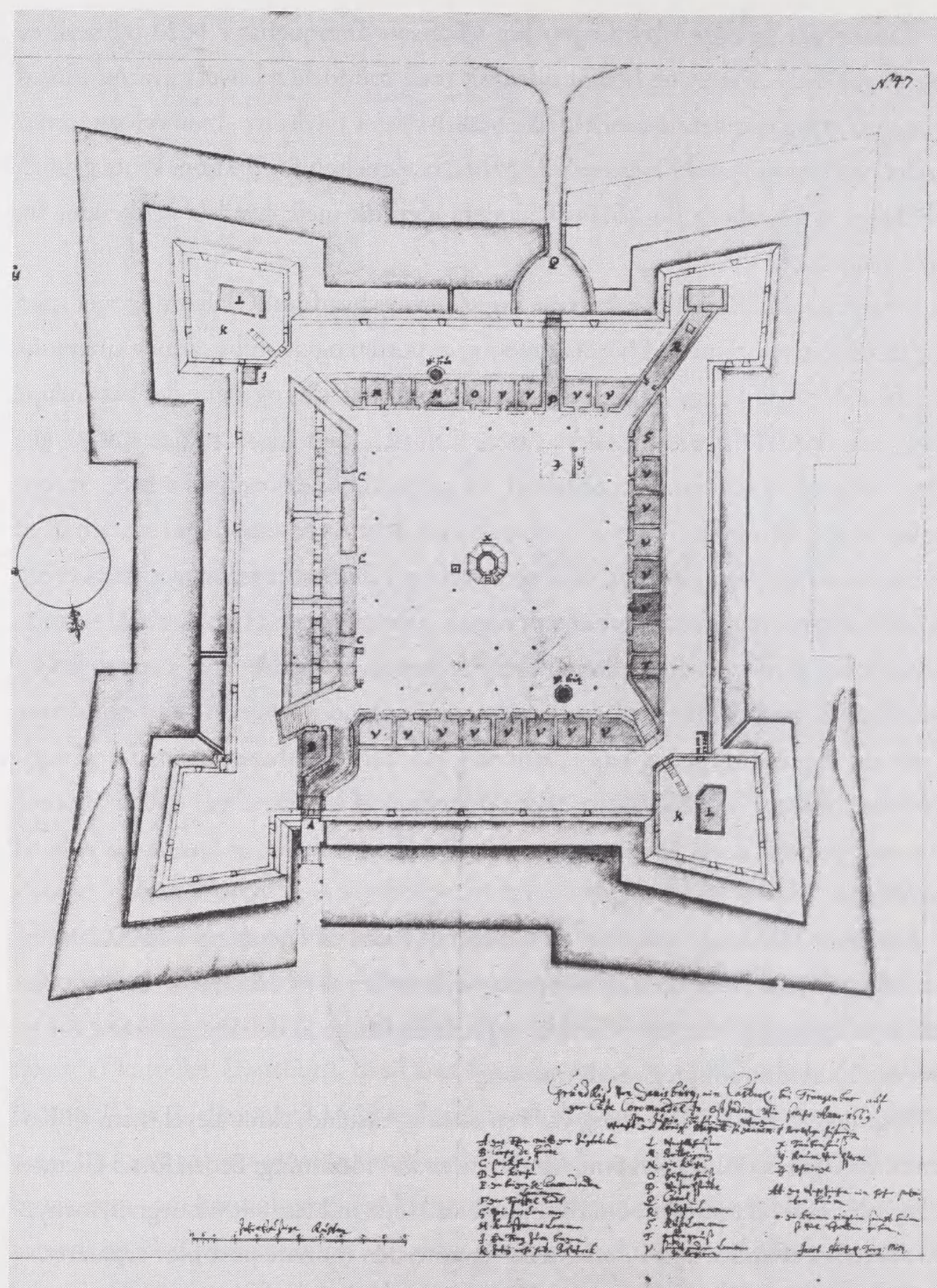

Ill. 2. Jacob Storzells kort over Dansborg 1669. Frederik 5.s Atlas, bd. 48, nr. 47.

muret dem højere end tidligere. Samtidigt ønskede han at bygge en tilsvarende forstærkning af gravens yderside, kontrescarpen.

Fra 1. oktober 1645 til 31. august det følgende år findes et driftsregnskab, der viser, at der blev bygget mure og indkøbt endog meget store mængder af mursten 
og kalk, men som ikke fortæller noget om, hvor der blev arbejdet. Dansborg har højst sandsynligt fået sine murstenbeklædte bastioner i denne intense renoveringsperiode.

Dansborgs tilstand efter reparationen ses af en fin lille tegning fra 1669, der også findes i Ingeniørkorpsets gamle kortsamling (ill.2) ${ }^{6}$.

1671-kortenes måske mest interessante oplysninger berører befæstningen af selve Tranquebar by: Fra Dansborg udgår en fæstningslinie mod vest. Den buer mod nord og igen mod øst tilbage mod det Indiske Ocean, så byen helt lukkes inde. Fæstningsringen er fuldt optrukket på godt 2/3-del af sit forløb, hvor den også er forsynet med små bastioner i den ældre nederlandske maner med flanker, der står med 90 grader på hovedvolden.

Midt på den nordlige del af fæstningen ændrer muren karakter og står ud mod oceanet i en ganske enkel streg. På dette forløb ligger der to rondeller, mens muren afsluttes mod vandet af et lidt uregelmæssigt, kantet hjørneværk. Rondellerne her er typiske exempler på et flankeforsvar fra 1500-tallets fæstningsbyggeri, hvor man som en overgangsfase til den bastionære form forsøgte at tilpasse den ældre befæstningsteknik til det moderne artilleris udfordringer.

Formodningen om at dette forløb hører til en ældre fase af fæstningsbyggeriet bekræftes også af andre oplysninger på de to kort: Både Hammersheimb og Hoffmann har med en stiplet linie angivet den oprindelige placering af en mur med rondeller af denne ældre type, dér hvor kortene har den nye bastionære front. Denne mur udgår fra Nørregade og følger en retning mod vest og ender i en ældre rondel, der oprindeligt har været befæstningens nordvesthjørne. På kortene omtales denne som „ein alt(es) Bolwerck so itzt ruiniret“, altså et gammelt bolværk, der nu ligger i ruiner. Muren drejer herfra skarpt mod syd, og kan følges forbi den gamle admiralhave med admiralhuset mod vest, som ligger som en stor rektangulær bygning flankeret af to tårne.

Lige før muren løber sammen med den nye bastionære vold ses i punkteret streg endnu en rondel, dog af yderst beskedne dimensioner.

Den nye fæstningslinie blev lagt udenfor det gamle forløb. Derved blev den islamiske moske (På kortene betegnet „H“) inddraget i byen, hvad den tidligere ikke havde været. På Hoffmanns kort, men ikke på Hammersheimbs gengivelse, ses moskeens område som et regelmæssigt rektangel i punkteret streg, hvis ene hjørne rager ud over den ny befæstningslinie. Det kan betyde, at fæstningslinien først meget 
sent i forhold til 1671 er blevet lagt henover arealet, eller at fæstningslinien endnu blot har været på planlægningsstadiet på dette tidspunkt. Den første forklaring synes at være den korrekte. På begge kort er voldlinien fuldt optegnet i den traditionelle grønne farve, der markerer existerende anlæg, mens man normalt anvendte gult til projekterede værker. Desuden er den bastionære front ikke lagt om de nordlige dele af fæstningen, hvor de gamle anlæg jo endnu ses som en del af linien. Havde tegningen vist et projekt, havde det naturlivis omfattet hele byen. 1671-kortene må altså vise tilstanden som fæstningen så ud dette år.

På Hammersheimbs kort ses endvidere, at den moderne stumpvinklede sydfront, der forbandt byens befæstning med Dansborgs bastioner, har afløst et ældre anlæg med mindst to rondeller. Muren har rimeligvis været ført helt ud til oceanet, men resterne af den er blevet brudt ned, da Dansborg blev bygget.

Rundt om befæstningen er der aftegnet en voldgrav, der er bred ud for de 2/3dele af fæstningen, der udgøres af den nye bastionære front. Ud for de ældre anlæg mod nord er den derimod ganske smal.

De samtidige kilder er yderst få, og megen omtale af forholdene ses ikke af det bevarede kildemateriale.

Byens befæstning omtales dog $\mathrm{i}$ et missive til kommandant Eskild Andersen Kongsbakke fra 22. oktober 1669. Man har fra den hollandske residensby på Java hørt, at nayaken af Tanjore i juli 1668 havde besat Tranquebar by og krævet 8.000 gylden af indbyggerne. For at hindre gentagelser heraf skal indbyggerne sørge for at bringe "den begyndte fortifikation “ til fuldkommenhed, så lignende overfald undgås i fremtiden. Eskild Andersen Kongsbakke skulle endvidere sørge for, at byen forblev ubefæstet mod Dansborg. ${ }^{7}$

$\mathrm{Nu}$ var det meget spredt, hvad man i København vidste om Tranquebars forhold: Korrespondancen var ikke hyppig, men det står fast, at man i 1668 i hvert fald vidste, at byen var ved at blive befæstet, og at forsvarsværkerne endnu ikke var blevet færdige.

At denne befæstning må være identisk med den nyere bastionære front, man ser på 1671-kortene, må være indlysende. Den havde tilsyneladende været undervejs i nogle år, men var - som kortene viser - endnu i 1671 uafsluttet og de gamle værker lå stadigvæk i nord.

Befæstningen rummede på dette tidspunkt altså et nyere element, den bastionære front, og et ældre, den enkle mur med rondeller, som kan spores om hele anlægget. 
Det passer fint med udviklingen af periodens fæstningsteknik, hvor rondeller efterhånden afløstes af bastioner. En oplysning i indexet bekræfter da også, at den stiblede linie, der angiver murens forløb, viser hvorledes fæstningen tidligere („wie vor") var placeret.

En mur med en port mellem Dansborg og Oceanet forklares som nyopført og den er da rimeligvis yngre end den bastionære linie - eller måske netop fra 1671 . Denne mur hører kun delvis med til byens befæstning, og virker da også nærmest som en sikring af Dansborgs tidligere helt ubeskyttede forterræn mod stranden.

Også bastionnavnene tyder på, at anlægget er fra 1660'erne: Navnene kendes bedst fra Matthias Seutters kort fra 1720'erne, og de falder i to grupper: Den første gruppe, der er opkaldt efter kongen og hans hus, omfatter også Dansborgs fire bastioner, der blev kaldt Kongen, Dronningen, Prins Christian og Prins Frederik. Bybefæstningens sydlige voldstrækning havde to bastioner, opkaldt efter Prins Georg og Gyldenløve.

De følgende bastioner (fra Gyldenløves og nord/nordøst på) er opkaldt efter Danmark, Norge og Holsten, og de to rondeller mod nord kaldtes Delmenhorst og Oldenburg. Det afsluttende væk mod oceanet hedder Sjællands Bastion.

Det er navngivning, der kan føres tilbage til de tilsvarende bastionnavne fra 1660 'ernes Fredericia og Nyborg, og som ikke optræder i dansk navngivningsskik fra dette årti ${ }^{8}$. Navngivningen kan naturligvis ikke direkte datere de enkelte dele af fæstningen, hvad navnene på de gamle rondeller jo klart viser. Navnet Prins Georgs Bastion tyder på, at navngivningen blev foretaget før tronskiftet i 1670, da der ikke er exempler på, at han optræder i de bastionnavne, Christian den 5 . navngav i sin regeringstid. - Hvis denne formodning holder, rejser det til gengæld et nyt problem. For hvor gammel er så det anlæg, som det erstatter?

Her skal endnu et kortarbejde drages ind i overvejelserne: Gregers Daa Trellunds kort over Tranquebar fra 1730'erne, der findes i to varianter ${ }^{9}$. Det bygger på et ældre arbejde fra 1690'erne af ubekendt herkomst. Kortet er udformet som en eleveret plan med bygninger set skråt oppefra uden perspektivforkortning - ganske som det kendes fra Peder Hansen Resens grundplaner af de danske byer til Atlas Danicus fra 1677. På mange måder er kortets gengivelser af Tranquebars bygninger og gårde overfladisk og tvivlsom i detaljer, men fæstningsringen synes at være gengivet pålideligt, og bekræfter - nu i billedform - den markante forskel på den gamle og den nye fæstningsline, der var så tydelig på kortene. 


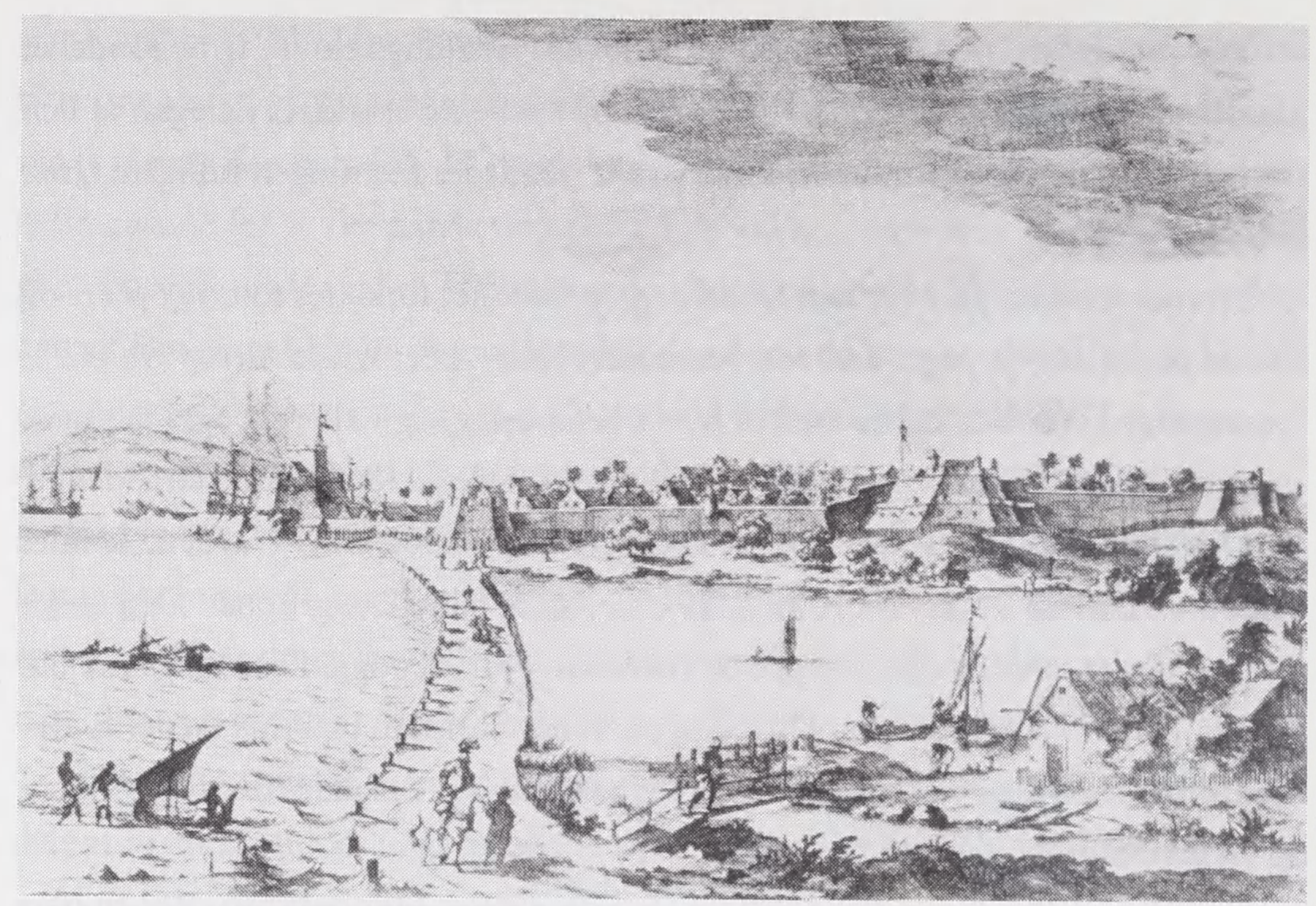

Ill. 3. Prospekt af Galle på Sri Lanka (Ceylon). Tegningen viser det portugisiske forsvarsanlæg, som senere hollænderne genopbyggede efter samme mønster, men større. Fra W.A. Nelson: The Dutch Forts of Sri Lanka. 1984.

Særligt interessant er Trellund-kortets afbildning af de bevarede dele af den gamle mur. De to gamle rondeller er fremstillet som murede sekskantede tårne i to stokværk placeret midt i bymuren med tre sider mod graven og tre mod byen. Den ene rondel har en lidt mere enkel udformning af sine skydehuller end den anden, der skulle flankere et stumpvinklet knæk på bymuren. Den har i begge stokværk - og på alle de tre sider, der kan ses på prospektet - parvise glugger. På rondellernes krenelerede top ses på begge bastioner to opmurede skilderhuse. Et ind mod byen og ét ud mod omegnen. Den uregelmæssige bastion ved stranden er her fremstillet som et meget stort syvkantet værk, der er forbundet med yngre værker langs stranden. Den synes ikke at have skydehuller eller lignende, til gengæld er dens top meget kraftigt bestykket med 22 kanoner og 1 morter, hvis man skal tro textoplysningerne på Trellunds kort.

Trellunds gengivelse bekræfter, at den ældre nordfront er bygget efter principperne for 1500-tallets ronddeler og kanontårne.

Den del af byens ældre befæstning, der allerede efter 1671-kortet var opgivet, ses ikke på Trellunds kort, borset fra det særprægede rektangulære admiralhus med sine to sidetårne, der på dette tidspunkt havde en rent civil funktion. 
Oplysningerne om admiralhuset bekræftes af de bygningsrids, som ses på Hammersheimbs og Hoffmanns kort. Både i rids og tegning minder bygningen temmelig meget om senmiddelalderens byporte, og det er sandsynligt, at der her faktisk er tale om en forlængst opgivet port, der senere, men i hvert fald før 1630’erne, da huset omtales første gang, er blevet ombygget til beboelse. En bygning med flankerende tårne placeret på en fæstningsmur kan næppe heller være andet end en port!

Der var åbenbart tradtion for en port på dette sted, og da man anlagde den bastionære front, placerede man også en port dér. Selvom den ikke havde direkte forbindelse med byens gadenet, åbnede den dog adgang til den store plads, der var opstået ved afsnøringen af den gamle befæstning.

Det har været foreslået, at den ældre befæstning stammer fra en ni måneder lang belejring af byen i midten af 1660'erne „hvorunder Eskild Andersen Kongsbakke skal have opført mur, kanontårne og rondeller ${ }^{10}$. Denne påstand er imidlertid næppe holdbar, da denne befæstning i så fald skulle være opført i en for samtiden fuldstændig forældet befæstningsmaner, som man ikke engang benyttede sig af i 1620'erne, da man opførte Dansborg.

Med den moderne befæstning dateret til sidste halvdel af 1660'erne, synes det også at være urimeligt, om man ganske få år forinden skulle have anlagt at så vidløftigt anlæg i en forældet udformning.

Det er dog på ingen måde let at komme en datering af de ældre værker nærmere, for vi ved forbløffende lidt om byggeaktiviteterne i og omkring Tranquebar fra Giedde forlod byen i 1621 til 1669, da man genoptog den direkte kontakt med kolonien efter tre årtiers afbrydelse.

Der var imidlertid en vis byggeaktivitet i 1640'ernes Tranquebar, da den handlekraftige Willem Leyel var kommandant. Han var dog travlt optaget af forbedringerne på Dansborg, og det må være yderst tvivlsomt, om han også nåede at anlægge en befæstning omkring byen i den korte tid han fungerede.

Hvis vi går længere tilbage i tid kommer vi til grundlæggelsesårene i 1620'erne, da Ove Giedde anlagde Dansborg. Der er heller ikke noget i hans optegnelser, der blot antyder, at han skulle have påbegyndt et anlæg omkring byen ${ }^{11}$.

Hertil kommer, at muren med rondeller så udpræget viser tilbage til 1500-tallets fæstningsteorier, så de kan næppe være meget yngre. Tranquebar bys ældre befæstning må følgeligt være anlagt tidligere end danskernes ankomst.

Befæstningen, der ikke er indisk, må være opført af en europæisk magt, rimeligvis 
portugiserne, der allerede i 1506 havde interesser i „Trangambar“, som allerede før europæernes ankomst til Indien omkring 1500 havde været et vigtigt udskibningssted for handel med Malacca ${ }^{12}$. Sandsynligvis har portugiserne på et tidspunkt i løbet af 1500-tallet opført en befæstning som de så senere - uvist af hvilken grund - har forladt.

At byen har haft en portugisisk fortid, ses også af beliggenheden af den ældre portugisiske kirke: Den kommer efter opførelse af Dansborg til at ligge præcis midt i det nye fæstningsanlæg, omgivet af Dansborgs volde og bygninger på alle sider. Kirken er omtalt af Jon Olafsson, der besøgte byen i 1623 og i sine erindringer nævner, at bygningen havde tilhørt en portugisisk papist. Den blev på dette tidspunkt brugt af garnisonen ${ }^{13}$. Denne kirke må ikke forvexles med den kirke, der blev indrettet for den danske menighed på selve Dansborg i 1620'erne.

Placeringen af Dansborg tog altså ikke hensyn til den existerende bebyggelse, og byggeriet har vel ødelagt den sidste rest af byens ældre befæstningsanlæg på dette sted.

Uheldigvis er de tilgængelige kilder til portugisernes aktiviteter i Tranquebar begrænset, men vi ved, at de i Asien - i modsætning til andre europæiske magter har efterladt sig talrige 1500-tals befæstninger med muranlæg med rondeller af den type, vi genfinder i Delmenhorst og Oldenburg Bastioner i Tranquebar (ill. 3).

Men også portugiserne fulgte med $\mathrm{i}$ udviklingen af fæstningsteknikken, og allerede i slutningen af 1500-årene begyndte de en modernisering af deres ældre anlæg ved opførelsen af bastioner. Det ses f. ex. på en afbildning af Malacca, som de i 1651 overgav til hollændene, hvor man ser en moderne bastionær fæstning lagt uden om den gamle bymur med sine rondeller.

Der er derfor grund til at formode, at Tranquebars ældre bybefæstning er bygget engang i 1500-tallet af portugiserne, der senere har opgivet støttepunktet; murene er faldet sammen og er vel blevet brugt som stenbrud af egnens befolkning.

Først med danskernes ankomst i 1620 blev stedet befæstet igen: Det skete i begyndelsen med fortet Dansborg, der beskyttede byens red. Senere udvidedes befæstningen med et moderne voldanlæg om selve byen, der kun i grove træk fulgte den gamle bymur fra portugisernes tid. 
1 Det kongelige Bibliotek. Kortsamlingen. Ingeniørkorpsets Kortaflevering 1911, 18-33.

2 Det kongelige Bibliotek. Kortsamlingen. Frederik den 5.'s Atlas, bind 48, nr. 46.

3 Torben Hjelm: Dansborg, i: Architectura 9, 1987, s. 89-92.

4 Jon Olafsen: Islanderen Jon Olafssons Oplevelser som Ostindiefarer under Christian IV nedskrevne af ham selv. 1907. s. 70.

5 Som note 3, s. 98-101.

6 Som note 2, bind 48, nr. 47. - Dette kort er signeret af Jacob Storzell.

7 Rigsarkivet. Danske Kancelli. Ostindiske sager 1668-1699 fol. 69-70.

8 Bjørn Westerbeek Dahl: Prinser, feltherrer og vilde dyr. Lidt om bastionnavne i 1600- og 1700-tallet, i: Krigshistorisk tidsskrift. 1994. Årg. 30, nr. 1, s. 21-27.

9 Handels- og Søfartsmuseets på Kronborg, og: Det kongelige Biblioteks Kortsamling Ingeniørkorpsets Kortaflevering 1911. 18-3-7. Kortene har tidligere været genstand for en undersøgelse, se: Birthe Faarborg: Trellunds Trankebarkort 1733, i: Arkiv 1971, 3. bind, nr. 3, s. 242-269.

10 Ole Feldbæk: Tranquebar 1620-1845, i: Arkitekten 1979, s. 548.

11 Som note 3 og 5 .

12 Manuel de Feria e Sousa: Asia portuguesa. I. Nyudg. Lisbon 1945, s. 197.

13 H. H. Engqvist: Traquebars bygninger, i: Arkitekten 1979, s. 555. - Jon Olafsson: Anførte sted, s. 70. 